\title{
Vulnerability assessment of a heritage structure subjected to blast-induced ground motions
}

\author{
R. Pradeep Kumar', D. Srinagesh ${ }^{2}$, T. Seshunarayana ${ }^{2}$, R. K. Chadha ${ }^{2}$, \\ Narender Bodige $^{3, *}$, G. Suresh ${ }^{2}$, D. Hima Chandan ${ }^{1}$ and C. V. R. Murty ${ }^{4}$ \\ ${ }^{1}$ Earthquake Engineering Research Centre, International Institute of Information Technology, Hyderabad 500 032, India \\ ${ }^{2}$ CSIR-National Geophysical Research Institute, Hyderabad 500 007, India \\ ${ }^{3}$ Department of Civil Engineering, Anurag Group of Institutions, Hyderabad 501 301, India \\ ${ }^{4}$ Department of Civil Engineering, Indian Institute of Technology Madras, Chennai 600 036, India
}

\begin{abstract}
A ground-structure vibration response study was carried out at the Ramappa Temple near Warangal, Telangana, India, shaken by underground blasting undertaken at the neighbouring Devadula Lift Irrigation Project to build water tunnels. The intensities of vibrations were examined-subsurface and ground vibrations were measured using velocity meters, and shaking at the temple using accelerometers. The study concluded that high-frequency vibrations of the ground were filtered by the soft natural clay bed underneath, and vibrations at the temple structure were small and well below the levels that can cause damage to it. Here we present the scientific findings of the vibrations recorded during the blasts and their implications.
\end{abstract}

Keywords: Heritage structure, structural response, tunnel blasting, vibrations, vulnerability assessment.

THE Ramalingeswara Temple (also known as Ramappa Temple, built over a period of 40 years, around AD 1213) is situated in the Godavari graben at Palampet village, Warangal district, Telangana, India. Unlike typical temples of South India, those in the Kakatiya (Warangal) dynasty are not gigantic from outside. The structures are exquisitely decorated internally with carvings on stonewalls, columns and ceilings. The Ramappa Temple represents the brilliance and beauty of the Kakatiya art ${ }^{1}$. This temple was planned and sculpted by Vishwakarma Brahmin Sthapathi as a classical pattern on a star-shaped raised platform (1.2-2.0 $\mathrm{m}$ high); the exquisitely carved columns in the hall in front of the sanctum combine well both light and space wonderfully. The temple faced repeated wars, invasions and natural disasters - a major earthquake during the 17 th century caused some damage.

The then Government of Andhra Pradesh started a Devadula Lift Irrigation Project in Warangal district to irrigate over 6 lakh acres of land in the region through

*For correspondence. (e-mail: drnbodigece@cvsr.ac.in) tunnelling, to increase the use of water from River Godavari. One such tunnel passes close $(<1 \mathrm{~km})$ to the Ramappa Temple (Figure 1), and was under construction with underground blasting being done to ream the tunnel. This study presents results of: (i) ground shaking at the base of the temple by wave propagation from tunnel blasting, and (ii) structural response vibrations recorded at different levels of the temple structure.

\section{The Ramappa Temple}

\section{Structure}

The $12.19 \mathrm{~m}$ high star-shaped temple has an adjoining structure on either side within its precincts (Figure 2), with the Nandi Mandapam on the eastern side. In the evolution of the overall shape of the temple, columns were placed at the nodes, and beams (whose spans are limited by the flexural strength of the stone) were placed over these columns. Four columns were placed in the middle square and beams were placed on these columns in both directions over which roof slabs were placed. The other columns and beams were nested around them. Additional columns were inserted at the exterior, to balance the projecting cantilevers and other items (Figure 3 ). The roof was formed by the corbelling technique - the central opening between the four beams was filled with four corner triangular pieces to form a central square, which was plugged with a single square block. Then, the beams and other stones were placed one over the other through tongue and groove joints to achieve monolithic action by placing counterweights on them. The roof was built with light porous burnt clay bricks; this light roof seems to have been added at a later date to reduce the load on the foundation.

The temple is an exception in its siting. While most temples in India are built on strong competent rock and elevated ground, the heavy stone-built Ramappa Temple has been constructed on soft clayey rice fields in low 


\section{RESEARCH ARTICLES}

plains. The foundation of the temple has been rested on confined sand, which was considered to provide stability to the temple. Retaining walls were provided along the periphery of the elevated pedestal of the temple (Figure 4 ), and the enclosure was filled with sand confined by

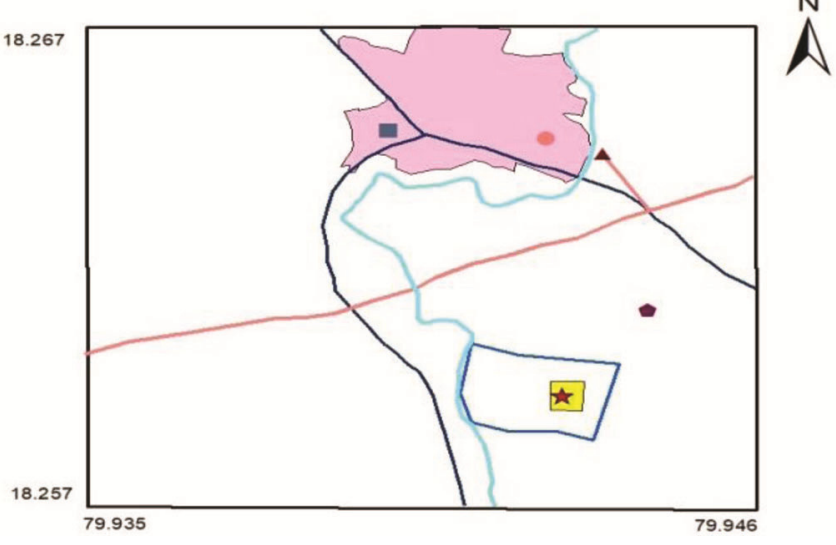

Figure 1. Plan view of the Ramappa Temple site: triangle indicates location where vibration sensors are placed.

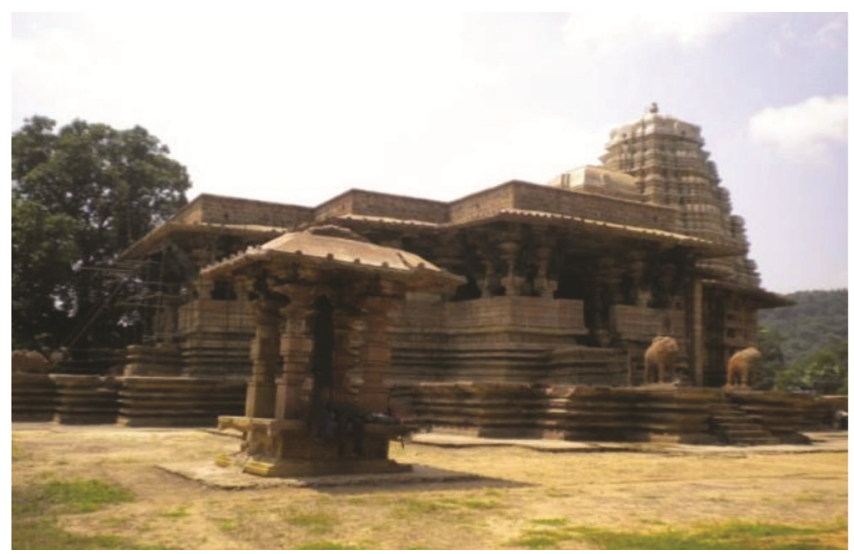

Figure 2. Southeastern view of the Ramappa Temple.

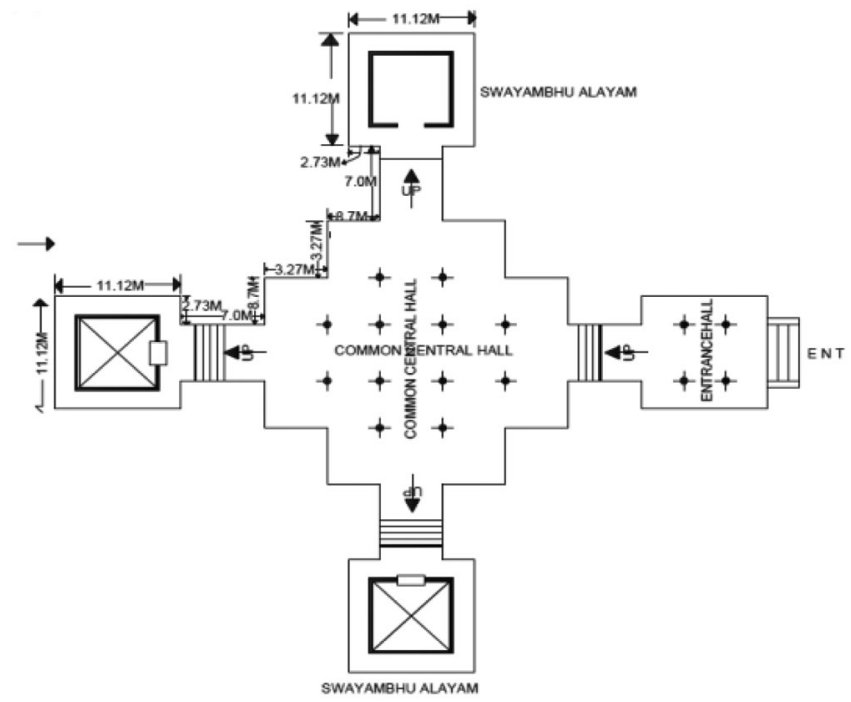

Figure 3. Plan of Trikuta Alayam form of the Ramappa Temple. ramming stone slabs. The columns of the temple directly rest on stone slabs and beams placed on this sand bath. However, seasonal presence of high water table in the adjoining rice fields and drying of the same during harvesting, resulted in long-term settlement of the clay. In turn, this led to loosening of the sand within the retaining walls along the perimeter of the elevated pedestal of the temple. This resulted in the settling of some columns by as much as $360 \mathrm{~mm}$, which eventually cracked the stone floor slabs and stone sill beams ${ }^{1}$. To mitigate this effect, the stones in the pyramid-shaped shikhara structure were partly replaced with light-weight bricks.

\section{Materials used}

During the 12th century, stones from the neighbourhood were preferred over other materials since they have withstood the vagaries of climatic and seasonal changes in that region for centuries. Any other material is susceptible to faster decay causing instability to the monuments ${ }^{2}$. Most stones used in the monuments in the Kakatiya region were granites, dolerites and sandstones, e.g. Ramappa Temple, Thousand Pillars Temple and Keerthi Thoranams at the Warangal Fort. In the Ramappa Temple, sandstones used were of the Sullavai Group belonging to the Pakhal Super-Group ${ }^{3}$. These sandstones exposed near the temple are pink-coloured with siliceous matrix. Occasional presence of white patches in the sandstones gives a decorative appearance and hence the name mottled Sullavai sandstones. These rocks have many vertical and inclined joints along with well-defined bedding planes. The sandstones were used in the roof and some beams

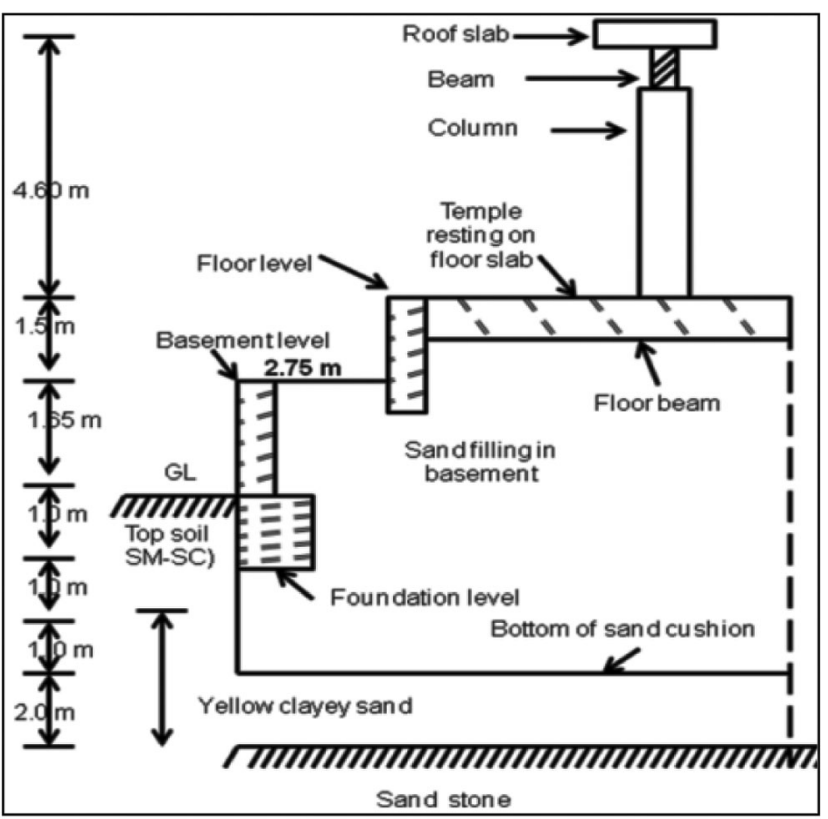

Figure 4. Details of the foundation the Ramappa Temple ${ }^{1}$.

CURRENT SCIENCE, VOL. 119, NO. 7, 10 OCTOBER 2020 
Table 1. Properties of materials used in the construction of the Ramappa Temple ${ }^{1}$

\begin{tabular}{lccrrr}
\hline & & \multicolumn{3}{c}{ Strength (MPa) } \\
\cline { 4 - 6 } Rock type & Density $\left(\mathrm{kN} / \mathrm{m}^{3}\right)$ & Porosity $(\%)$ & Compressive & Tensile & Shear \\
\hline Granite & $26.0-26.5$ & 0.2 & $100-200$ & $8-20$ & $14-50$ \\
Dolerite & $30.0-31.0$ & 0.1 & $200-300$ & $15-32$ & $25-60$ \\
Sullavai sandstone & $24.0-26.0$ & $0.8-0.9$ & $60-100$ & $5-11$ & $8-25$ \\
\hline
\end{tabular}

and columns; dolerites were used in the columns where load intensity was high. Sandstone used in the roof underwent exfoliation and loosening of mineral grains in the rocks. Table 1 shows properties strengths of stones used in the construction of the temple.

In masonry construction, joints are either rigid or flexible, and dry or wet depending on the expected behaviour in transmitting loads to members carrying the loads. In this, temple, joints are dry and relatively rigid. Thus, when members are placed one over the other, point contacts are generated, which increase the local stresses in the rocks. In a few walls and columns, dowel bars have been used to create monolithic action, when horizontal movements were noticed over a period of time due to settlements owing to flexible soil conditions underneath.

\section{Geological setting and seismotectonic environment}

The sandstone (Sullavai Group in Pakhal belt belonging to Godavari Supergroup) used in the temple was brought from downstream of the Ramappa Tank; they are exposed near Chelvai village. These rocks are presumed to be equivalent of the Rewa Group of the Vindhyan Supergroup. The general strike of the formations is NW-SE dipping NE, coinciding with the general trend of the major hill ranges in the region. They are pink-coloured and medium-grained with siliceous matrix. Occasionally, white patches are present in these sandstones giving a decorative appearance. The rocks exhibit vertical and inclined joints along well-defined bedding planes. The lineaments identified in the area are in three directions, namely NNE-SSW, NS-SW and E-W. The E-W trending lineament passes close to the temple premises.

The Geological Survey of India carried out geotechnical studies by drilling boreholes up to $60 \mathrm{~m}$ depth along the tunnel alignment. Three of these boreholes are at 600-800 $\mathrm{m}$ distance from the temple ${ }^{4}$; in these boreholes, the overburden soil thickness varies between 1.5 and $9.0 \mathrm{~m}$ followed by pink sandstone or grey shales underneath. The temple lies in Seismic Zone III according to the Seismic Zoning Map of India ${ }^{5}$. The largest earthquake of the region was $M_{\mathrm{w}} 5.7$, which occurred on 13 April 1969 , in Bhadrachalam epicentred about $90 \mathrm{~km} \mathrm{SE}$ of the temple $^{6}$. Prior to 1969 , earthquakes in this region during 1954, 1963 and 1968 had magnitude less than 4.5.
In the temple premises, the topsoil is clayey sand, up to a depth of about 3-6 m. Underlying this topsoil cover is the weathered and fractured sandstone up to $19 \mathrm{~m}$, followed by Sullavai sandstones, with structural features like joints, fractures and bedding plains.

\section{Geophysical measurements and data acquisition}

Four broadband digital seismographs (GURALP seismometers (60 sec, $50 \mathrm{~Hz}$ ), and REFTEK Digital Acquisition system with GPS) were employed. Four of these were operated for the entire study period. Station 1 was installed above the tunnel at ground level, station 2 at $100 \mathrm{~m}$ from the location of the blast in a house in Palampet village, station 3 at a distance of $\sim 500 \mathrm{~m}$ in the Gram Panchayat Office, and station 4 within the premises of the temple at ground level. The data were sampled at a rate of 100 sps. Peak ground acceleration (PGA), peak particle velocity, ground displacement and amplitude spectrum at the locations of the five sensors were obtained from vibrations generated by the blasts. Three charges of explosives, namely 49.92, 63.57 and $70.59 \mathrm{~kg}$ were used to create the four blasts; the $70.59 \mathrm{~kg}$ charge was used for the last two blasts.

\section{Site amplification}

The amplification of the seismic waves is estimated by dividing the spectral ratios of the horizontal and vertical $(H / V)$ components. The amplification depends on layer thickness, degree of compactness and age of the formation. The damage during an earthquake is generally larger over soft sediments due to the large amplification of ground motion compared to that on rigid outcrops. Local subsurface geological conditions amplify or de-amplify the ground motion depending on site geology. The Nakamura method, wherein the $H / V$ ratio is estimated for each site by dividing the Fourier amplitude spectral values of the horizontal and vertical components of ground vibrations $^{7}$, provides a good estimate when the ground has soft soil (low fundamental frequency) but not when it has stiff soil (high fundamental frequency) sediments ${ }^{8,9}$. Dominant frequencies and amplifications were estimated from the time-series data of ground vibrations generated by the blasts (Figure 5; on 29 September 2011); average $H / V$ spectral ratios were used to estimate the fundamental 
Table 2. Peak ground acceleration (PGA), peak particle velocity and peak displacement

\begin{tabular}{|c|c|c|c|c|c|c|c|c|}
\hline \multirow[b]{2}{*}{ Blast time } & \multicolumn{4}{|c|}{ PGA at various stations $\left(\mathrm{mm} / \mathrm{s}^{2}\right)$} & \multicolumn{2}{|c|}{ Peak particle velocity $(\mathrm{mm} / \mathrm{s})$} & \multicolumn{2}{|c|}{ Peak displacement (mm) } \\
\hline & Ramappa Temple & Gram Panchayat & Palampet & Tunnel & Ramappa Temple & Tunnel & Ramappa Temple & Tunnel \\
\hline 2011-09-28 14:03 & 0.493 & 1.825 & 19.304 & 21.63 & 0.008 & 0.272 & 0.800 & 24.4 \\
\hline 2011-09-29 04:38 & 0.413 & 1.621 & 14.395 & 14.91 & 0.007 & 0.241 & 0.510 & 14.5 \\
\hline 2011-09-29 14:37 & 0.551 & 1.889 & 15.523 & 22.32 & 0.100 & 0.274 & 0.665 & 23.9 \\
\hline 2011-09-30 05:58 & 0.595 & 2.616 & 22.722 & 28.34 & 0.100 & 0.385 & 0.940 & 25.9 \\
\hline
\end{tabular}
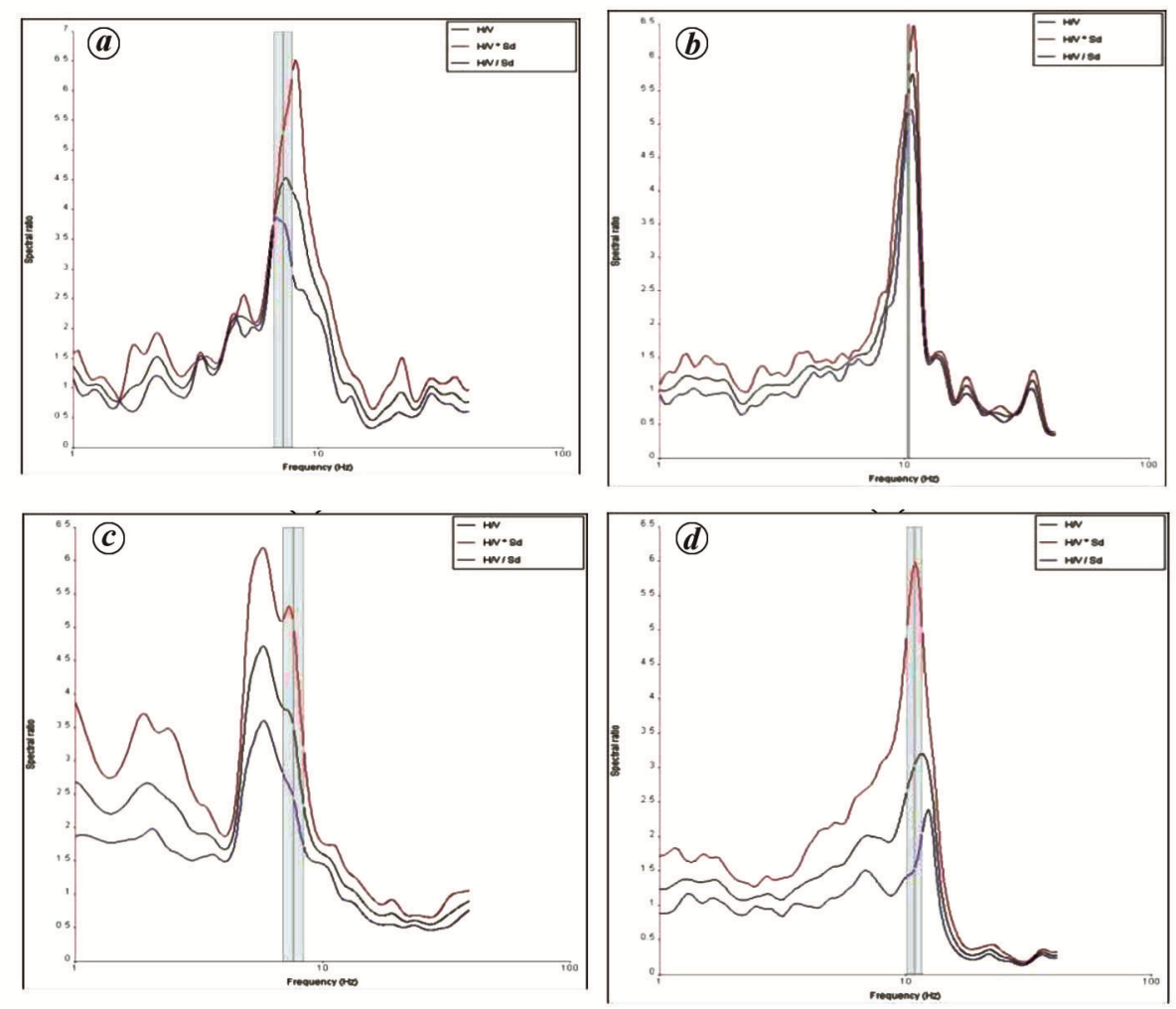

Figure 5. $H / V$ ratio at: (a) Ramappa Temple, (b) Gram Panchayat, (c) Palampet village and (d) Tunnel site.

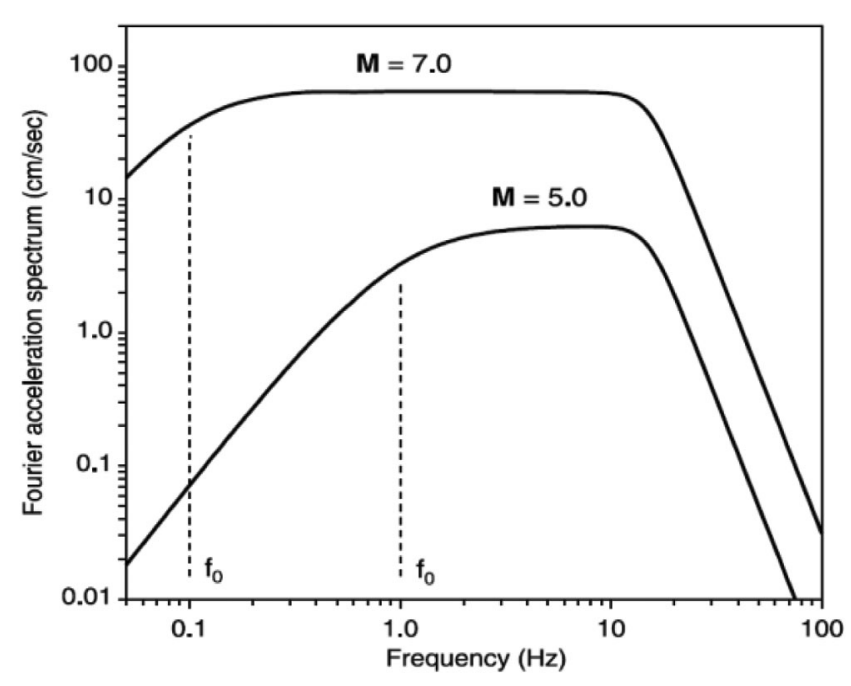

Figure 6. Typical Fourier amplitude earthquake acceleration spectra $^{10}$. resonant frequencies and amplitudes. The dark and thin lines represent $\mu+\sigma$ and $\mu-\sigma$ values of $H / V$ ratios respectively. The amplitudes of $H / V$ ratios varied in the range 3.0-5.5 at station 1 located at Gram Panchayat Office, and 3.0-4.5 at all other stations independent of their distance. The fundamental resonant frequency was $10 \mathrm{~Hz}$ at station 1 and $9.0 \mathrm{~Hz}$ above the tunnel and at Ramappa Temple. The small variation in resonant frequency indicates that the thickness of the soft soil is uniform (around $5 \mathrm{~m}$ ). Thus, the amplifications are governed by local site conditions rather than distance between blast source and measurement stations.

\section{Horizontal ground motion studies}

The Fourier amplitude spectra of the three components (two horizontal and one vertical) of the vibrations induced by the blasts were obtained; the horizontal 

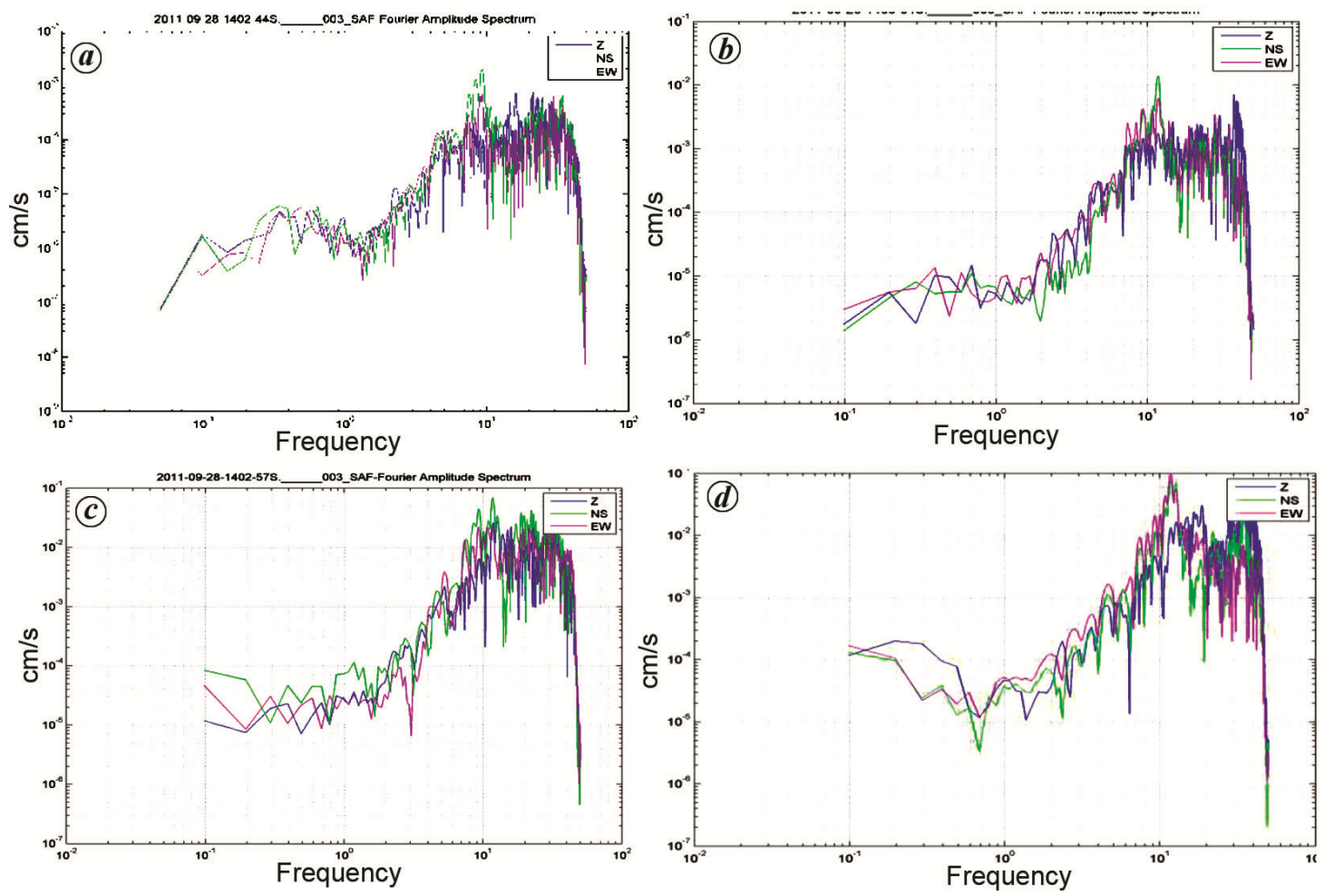

Figure 7. Fourier amplitude spectra of 28 September 2011 blast recorded at: (a) Ramappa Temple, (b) Gram Panchayat, (c) Palampet village and $(\boldsymbol{d})$ Tunnel site.

components, i.e. the $\mathrm{N}-\mathrm{S}$ and $\mathrm{E}-\mathrm{W}$ components, were amplified at specific frequencies (Table 2). Figure 6 shows typical spectra of earthquake ground shaking ${ }^{10}$. Here, as the magnitude (energy) of the shock increases, the rise time increases and thus the corner frequency $f_{0}$ decreases. Also, as the epicentral distance increases between source and the receiver, the corner frequency decreases. A similar analysis was carried out for vibrations generated by the blasts and recorded at the stations varying in distance. As the distance between the recording station and location of the blast increased, the corner frequency decreased.

The Fourier amplitude spectra of the vibrations at the four sites showed an increase in corner frequency from 7 to $\sim 10 \mathrm{~Hz}$, with decrease in epicentral distance (Figure 7). This is attributed to variations in elastic properties of the soil medium. Also, the dominant frequency and maximum amplitude varied with distance from the temple to the tunnel site. While the temple site shows a dominant frequency of $9 \mathrm{~Hz}$, the Gram Panchayat and the Palampet village sites show frequencies more than $10 \mathrm{~Hz}$, and the tunnel site between 9 and $\sim 40 \mathrm{~Hz}$ (Table 3 ). Thus, the amplitude increases closer to the location of the blast. Further, the relative horizontal ground motion spectra were studied with respect to that at the temple station (which sustained the smallest acceleration); the NS and EW components of the blasts were averaged to obtain the mean horizontal ground motion spectrum at each station.
Next, the mean horizontal spectrum of vibrations at the temple was removed from the corresponding spectra at individual stations to obtain the relative ground motion spectrum for all the blasts. Figure 8 depicts the relative ground motion spectrum at five sites; acceleration, velocity and displacement values decrease from tunnel to temple.

The Fourier amplitude spectra of the four blasts (Figure 8) suggest that: (1) Motion at the tunnel site has several frequencies $(5-40 \mathrm{~Hz})$, showing its proximity to the location of the blast. (2) Spectral peaks differ in two orders of magnitude $\left(10^{-3}-10^{-1} \mathrm{~cm} / \mathrm{s}^{2}\right)$. (3) Dominant frequency is $9 \mathrm{~Hz}$ at the temple site. (4) Spectral amplitudes decrease as distance increases from the location of the blast site, indicating the spreading of energy across a frequency range. (5) Difference in peak spectral values increases from Gram Panchayat to tunnel site in the range $10^{-3}-10^{-1}$. (6) Peak particle velocity and peak ground acceleration increase from at the base of temple $\left(0.1 \mathrm{~mm} / \mathrm{s}\right.$ and $\left.0.6 \mathrm{~mm} / \mathrm{s}^{2}\right)$ to the tunnel $(0.385 \mathrm{~mm} / \mathrm{s}$ and $28.34 \mathrm{~mm} / \mathrm{s}^{2}$ ). (7) Vibrations are uniform from the blasts $\sim 5 \mathrm{~Hz}$, and differences in the spectra are insignificant.

\section{Estimation of shear wave velocity}

\section{Data acquisition}

A 24-channel seismic data acquisition system (Strata Visor NZ-XP, M/s Geometrics) with Geode and $4.5 \mathrm{~Hz}$ 

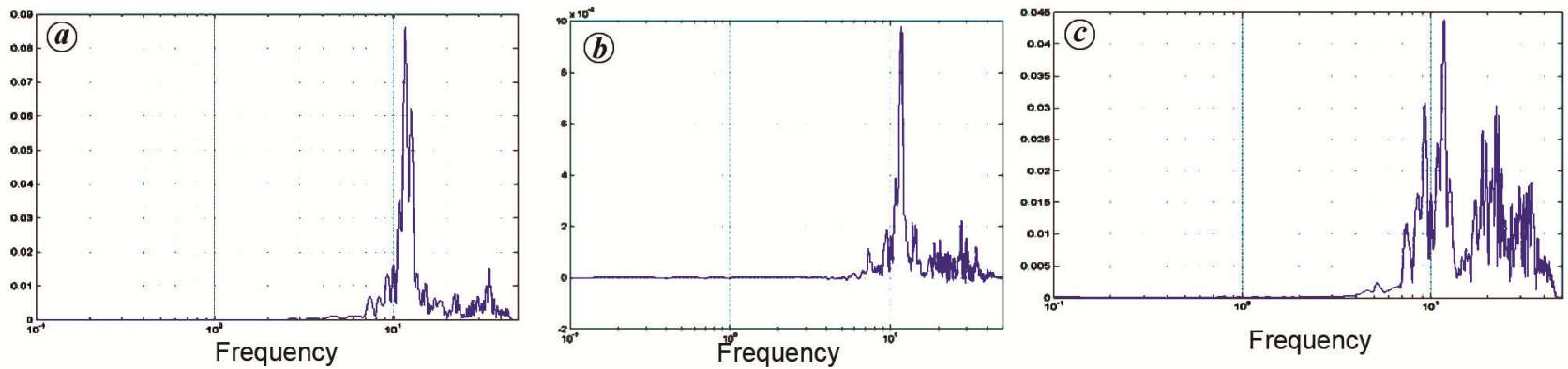

Figure 8. Fourier amplitude spectra of the differential motion at three sites (with respect to that at the temple) generated by the 28 September 2011 blast at: (a) Gram Panchayat, (b) Palampet village and (c) Tunnel sites.

Table 3. Predominant frequency recorded at different locations of the temple site

\begin{tabular}{lc}
\hline Location & Average predominant frequency $(\mathrm{Hz})$ \\
\hline West of temple & 3.5 \\
East of temple & 6.0 \\
North of temple & 7.0 \\
South of temple & 9.0 \\
Across the proposed surge pool & 6.0 \\
\hline
\end{tabular}

geophones fitted with spikes were used. Surface-wave seismic data were acquired along a traverse with geophone interval of $1 \mathrm{~m}$ and shot interval of $1 \mathrm{~m}$. Standard roll-along technique was used to achieve a shot gather at $1 \mathrm{~m}$ interval (Figure 3.12). The source to nearest receiver distance (offset distance) was kept constant at $5 \mathrm{~m}$.

\section{Data processing}

Data at each blast consist of 24 traces. These data require some pre-processing before using the MASW software. This involves: (1) conversion of data field record format to data processing format; (2) pre-processing data inspection for removal of bad records/traces; (3) examination for consistency of surface wave alignment with neighbouring shot-gather records; (4) filtering and muting of unwanted signals to enhance surface wave data; (5) velocity and frequency analysis which helps in estimating the surface wave phase velocity; (6) analysis of each blast record which results in the generation of dispersion curve; (7) ensuring spectral properties of the time/offset data to be consistent with maximum and minimum frequency and phase velocity values contained in the dispersion curve; (8) each dispersion curve is individually inverted into a depth-shear wave velocity plot, and (9) a $2 \mathrm{D}$ contour plot (or image) of shear wave velocity field produced by gathering all the depth-velocity traces in sequential order.

The profile of shear wave velocity $\left(V_{\mathrm{s}}\right)$ near the ground surface reflects the shear modulus of the type of soil strata, and thereby its stiffness. Multi-channel analysis of surface waves (MASW) technique was employed to eva- luate the near-surface $V_{\mathrm{s}}$ profile, which is valid up to $80 \mathrm{~m}$ depth. The key observations are as follows:

(1) $V_{s}$ varies $(150-650 \mathrm{~m} / \mathrm{s})$ along profiles 1 to 5 (Figure 9); the lowest is $<250 \mathrm{~m} / \mathrm{s}$ at $5 \mathrm{~m}$ depth (corresponding to topsoil layer) and the highest is $>650 \mathrm{~m} / \mathrm{s}$ at $10 \mathrm{~m}$ depth (corresponding to sandstone). This observation agrees with borehole data and exposed section at the excavated Audit Tunnel 4.

(2) The temple has consolidated soil layer beneath it; with the velocity varying laterally, indicating the variation in the elastic properties of the soil.

(3) Profile 5 across the proposed location of the surge pool shows low $V_{s}(150-300 \mathrm{~m} / \mathrm{s})$ on the western side and high $V_{s}(800-1000 \mathrm{~m} / \mathrm{s})$ on the eastern side.

(4) Dominant frequency around the temple varies (3.5$9.0 \mathrm{~Hz}$ ), indicating variation in soil cover.

(5) The stiffness computed is low $(<200 \mathrm{kPa})$ in the topsoil (thickness 5-10 m) and high (600-1000 kPa) in the semi-weathered to compact sandstone below it.

\section{Structural measurements}

The temple faces the east. Triaxial vibration sensors were used at different locations in the temple to record vibrations (Figure 10). Each sensor measured accelerations along three orthogonal directions, i.e. two horizontal (EW and NS) and one vertical (V) direction. Sensitivity of the sensor was $0.001 \mathrm{gal}\left(\mathrm{cm} / \mathrm{s}^{2}\right)$ and range $\pm 2 \mathrm{~g}\left( \pm 19.6 \mathrm{~m} / \mathrm{s}^{2}\right)$. Seven sensors (itk00, itk01, itk02, itk03, itk04, itk05 and itk06) were placed at different locations (Figure 11). Sensor itk00 was placed in the sanctum area, sensors itk01 and itk02 at the plinth level, sensors itk03, itk04 and itk05 at roof level, and sensor itk06 at the mid-height of the roof. Data from the sensors were recorded on a computer with real-time graphical display of vibrations; sampling rate was $0.01 \mathrm{~s}$.

\section{Ambient vibration response}

Ambient vibrations around the temple were recorded initially after setting up the sensor network (Tables 4 and 5). 

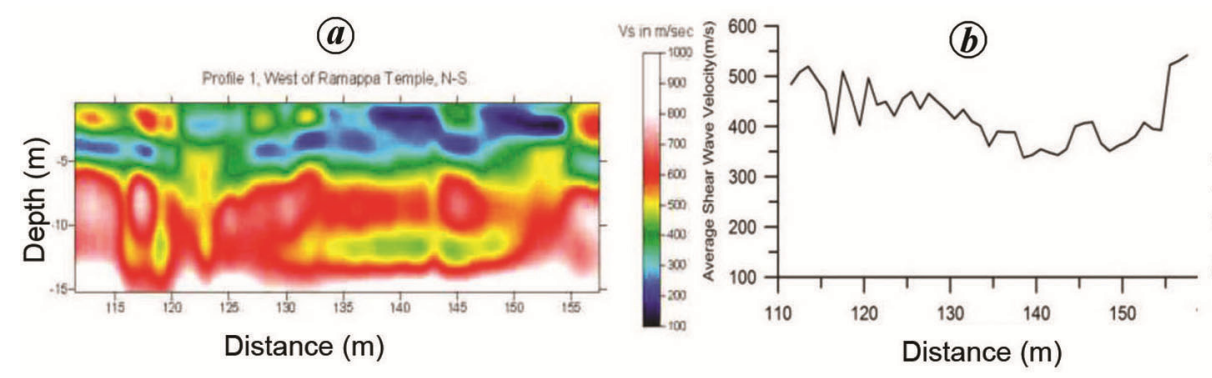

Profile 1: West of Ramappa Temple

(a)

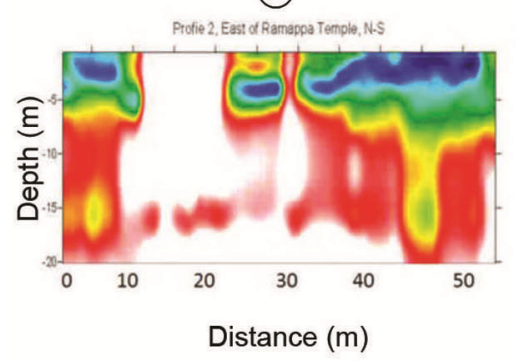

(a)

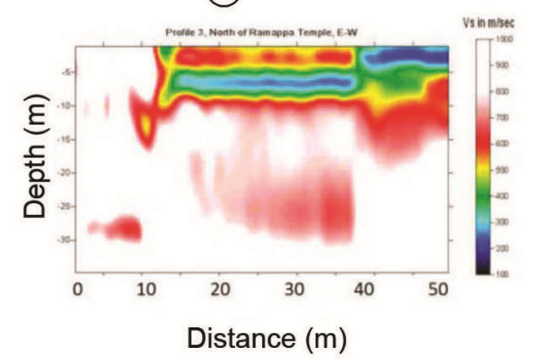

(a)

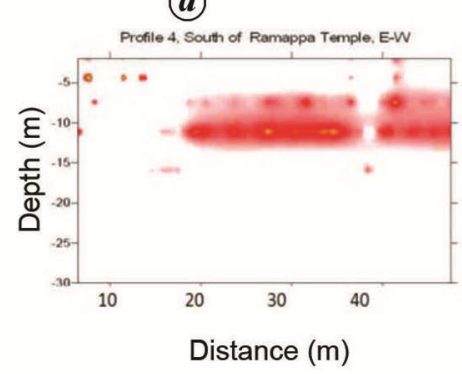

(a)

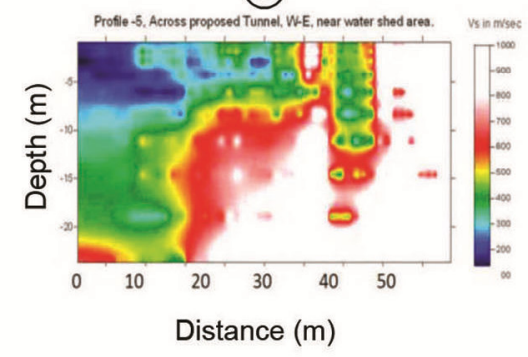

(b)

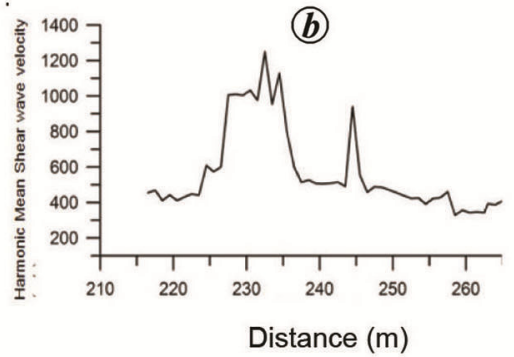

Profile 2: East of Ramappa Temple

(b)

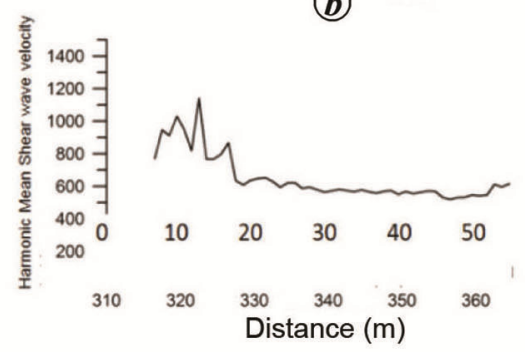

Profile 3: North of Ramappa Temple

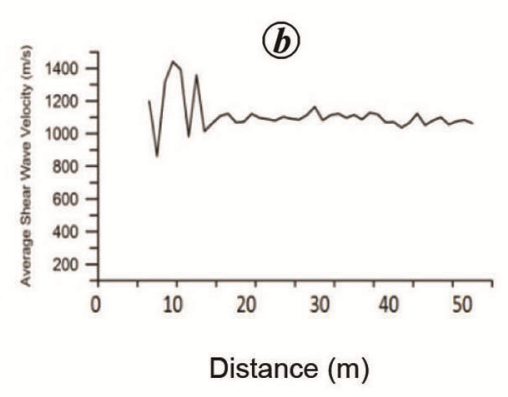

Profile 4: South of Ramappa Temple

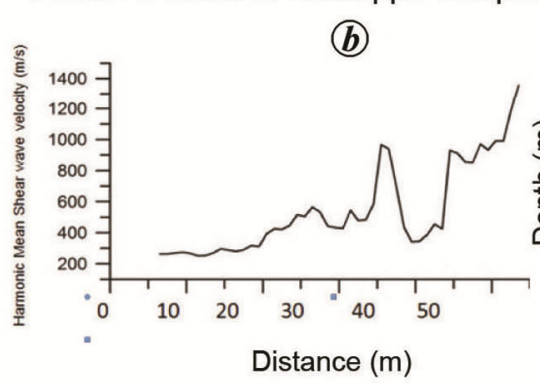

(c)

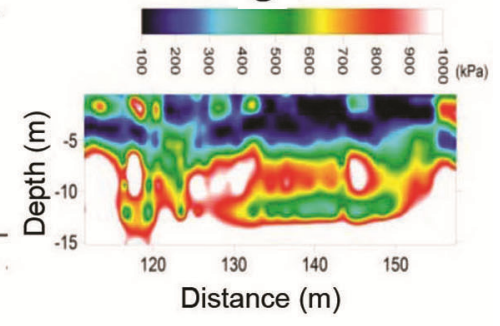

(c)

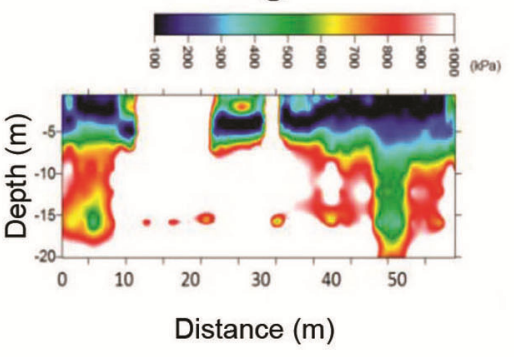

(c)

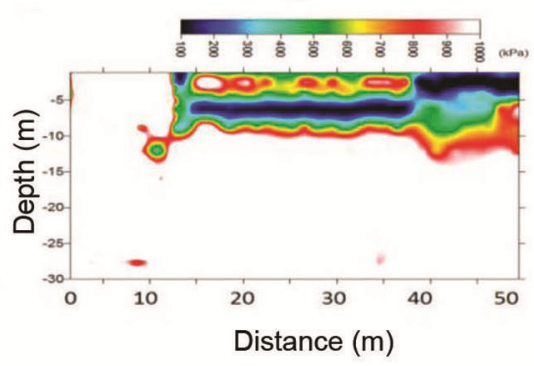

(c)

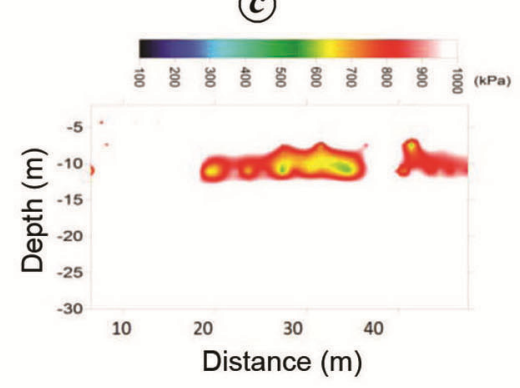

(c)

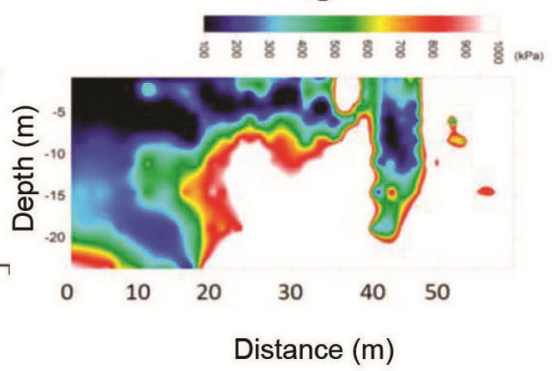

Profile 5: Along the site of the proposed surge pool

Figure 9. Ground profiles around the temple: $(\boldsymbol{a})$ shear wave velocity, $(\boldsymbol{b})$ harmonic mean $V_{\mathrm{s}}$ and $(\boldsymbol{c})$ stiffness profile. 

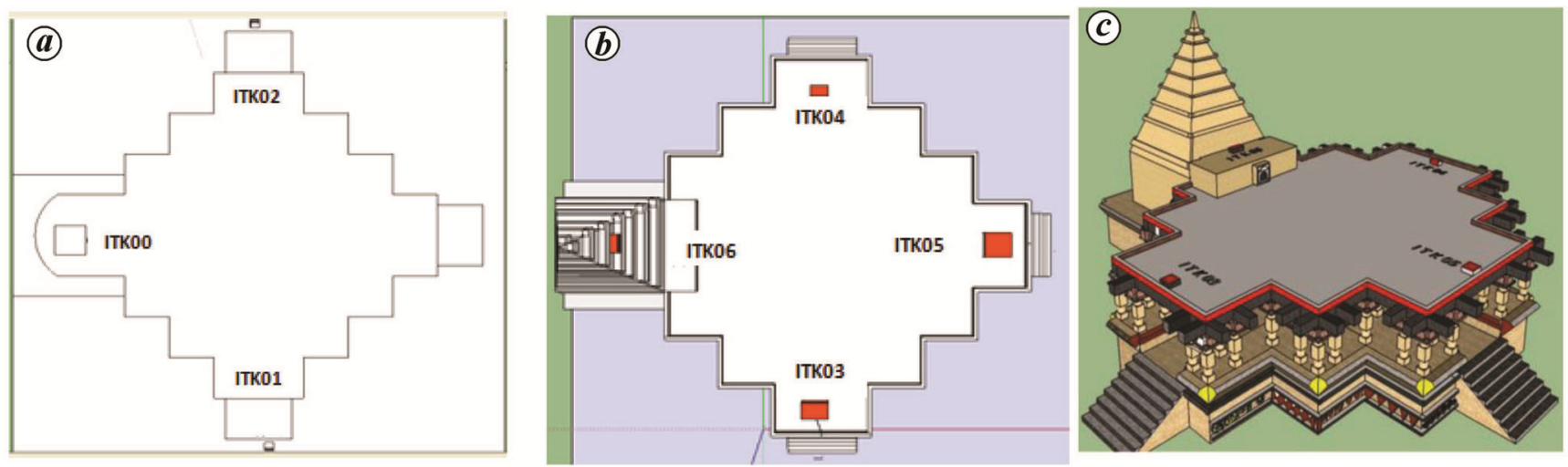

Figure 10. Location of seven sensors on the temple structure: (a) floor level, $(\boldsymbol{b})$ roof level, and (c) in 3D view.
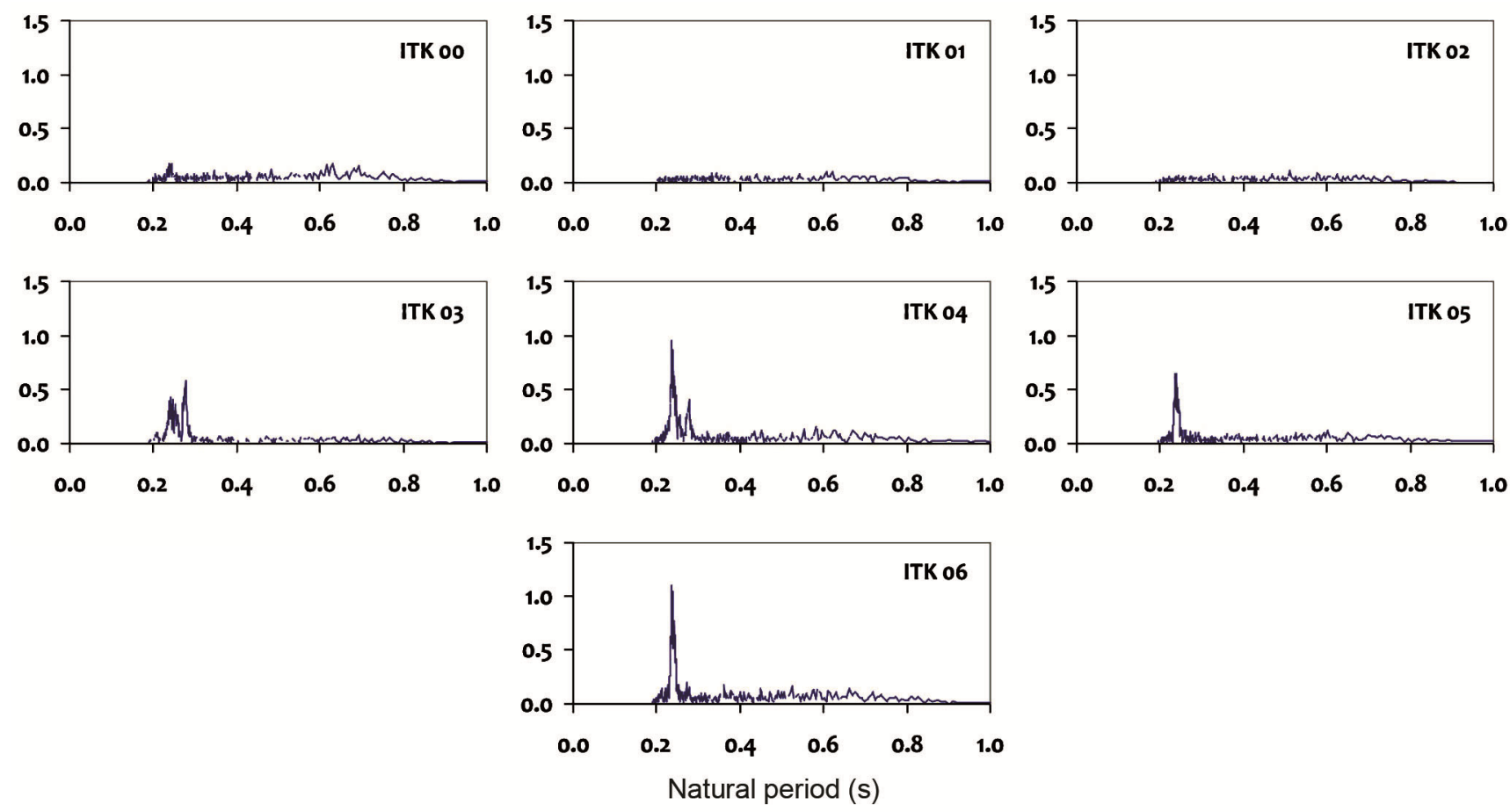

Figure 11. Fourier amplitude $\left(\mathrm{mm} / \mathrm{s}^{2}\right)$ spectra of acceleration of vibrations in the seven sensors recorded along N-S direction under blast 4 .

The temple structure is $18 \mathrm{~m}$ high, which is nearly that of a seven-storey RC building. Generally, fundamental natural periods of seven-storey RC buildings with unreinforced masonry infill walls are around $0.35-0.45 \mathrm{~s}$. The amplification in the Fourier spectral acceleration value from sensor itk00 to the sensor itk06 at mid-height of the gopuram was $0.28 \mathrm{~mm} / \mathrm{sec}^{2}$. Spectra of ambient vibration of the temple structure showed predominant natural periods of $0.31 \mathrm{~s}$ along the $\mathrm{E}-\mathrm{W}$ and $0.34 \mathrm{~s}$ along the $\mathrm{N}-\mathrm{S}$ directions.

\section{Vibration due to blasting}

Fourier amplitude spectra of the acceleration time histories at all seven sensors are shown in Figures 11-13 under blast 4 of $70.59 \mathrm{~kg}$ charge at the tunnel site (at an azimuth of $9^{\circ} \mathrm{E}$ to the $\mathrm{N}-\mathrm{S}$ axis of the temple structure). Tables 6 and 7 show absolute peak amplitudes and absolute peak spectral amplitudes. The amplification in Fourier spectral acceleration from sensor itk00 to that at sensor itk06 under blast 1 was $0.851 \mathrm{~mm} / \mathrm{sec}^{2}$ in the $\mathrm{E}-\mathrm{W}$ direction and $0.487 \mathrm{~mm} / \mathrm{sec}^{2}$ in the $\mathrm{N}-\mathrm{S}$ direction. Under blasts 2 , 3 and 4 , these were $0.55,0.809$ and $1.141 \mathrm{~mm} / \mathrm{sec}^{2}$ in the E-W direction and $0.165,0.329$ and $0.3 \mathrm{~mm} / \mathrm{sec}^{2}$ in the $\mathrm{N}-\mathrm{S}$ direction respectively. Thus, amplification is more along the $\mathrm{E}-\mathrm{W}$ direction than along the $\mathrm{N}-\mathrm{S}$ direction.

\section{Results and conclusion}

Vibrations were recorded at the 800-year-old Ramappa Temple in Warangal district, during underground blasts at a Lift Irrigation Tunnel about $900 \mathrm{~m}$ away. The impact of 
RESEARCH ARTICLES

Table 4. Peak acceleration of vibrations due to ambient vibration

\begin{tabular}{lccccccccc}
\hline & & \multicolumn{6}{c}{ Peak acceleration $\left(\mathrm{mm} / \mathrm{s}^{2}\right)$} \\
\cline { 3 - 9 } Vibration & Direction of measurement & 0 & 1 & 2 & 3 & 4 & 5 & 6 \\
\hline Ambient & North-South & 0.088 & 0.091 & 0.040 & 0.078 & 0.140 & 0.075 & 0.126 \\
vibration & East-West & 0.051 & 0.052 & 0.038 & 0.089 & 0.096 & 0.134 & 0.141 \\
& Vertical & 0.135 & 0.035 & 0.113 & 0.554 & 0.230 & 0.084 & 0.057 \\
\hline
\end{tabular}

Table 5. Peak Fourier acceleration spectral values of vibrations due to ambient vibration

\begin{tabular}{lccccccccc}
\hline & & \multicolumn{5}{c}{ Peak acceleration $\left(\mathrm{mm} / \mathrm{s}^{2}\right)$} \\
\cline { 3 - 9 } Vibration & Direction of measurement & 0 & 1 & 2 & 3 & 4 & 5 & 6 \\
\hline Ambient & North-South & 0.088 & 0.091 & 0.040 & 0.078 & 0.140 & 0.075 & 0.126 \\
vibration & East-West & 0.051 & 0.052 & 0.038 & 0.089 & 0.096 & 0.134 & 0.141 \\
& Vertical & 0.135 & 0.035 & 0.113 & 0.554 & 0.230 & 0.084 & 0.057 \\
\hline
\end{tabular}

Table 6. Peak acceleration of vibrations due to blasts

\begin{tabular}{llccccccc}
\hline & & \multicolumn{7}{c}{ Peak acceleration $\left(\mathrm{mm} / \mathrm{s}^{2}\right)$} \\
\cline { 3 - 9 } Vibration & Direction of measurement & 0 & 1 & 2 & 3 & 4 & 5 & 6 \\
\hline Blast 1 & North-South & 0.529 & 0.980 & 0.842 & 0.799 & 0.823 & 1.894 & 1.016 \\
& East-West & 0.673 & 0.831 & 0.994 & 0.723 & 0.709 & 0.688 & 1.524 \\
& Vertical & 0.957 & 1.826 & 1.756 & 2.568 & 0.900 & 5.174 & 0.899 \\
Blast 2 & North-South & 0.347 & 0.629 & 0.568 & 0.566 & 0.707 & 0.418 & 0.512 \\
& East-West & 0.594 & 0.687 & 0.496 & 0.897 & 0.560 & 0.825 & 1.144 \\
& Vertical & 0.989 & 0.993 & 0.787 & 2.276 & 0.741 & 1.326 & 0.883 \\
Blast 3 & North-South & 0.857 & 0.874 & 0.886 & 1.067 & 0.990 & 0.766 & 1.186 \\
& East-West & 0.861 & 0.684 & 0.535 & 1.091 & 1.109 & 0.982 & 1.670 \\
& Vertical & 1.250 & 1.279 & 1.497 & 3.178 & 1.142 & 1.650 & 1.951 \\
Blast 4 & North-South & 0.647 & 0.943 & 0.653 & 1.006 & 0.956 & 0.869 & 0.947 \\
& East-West & 0.804 & 1.183 & 0.783 & 1.135 & 0.908 & 0.848 & 1.945 \\
& Vertical & 1.654 & 4.863 & 2.133 & 4.886 & 1.203 & 3.008 & 1.224 \\
\hline
\end{tabular}
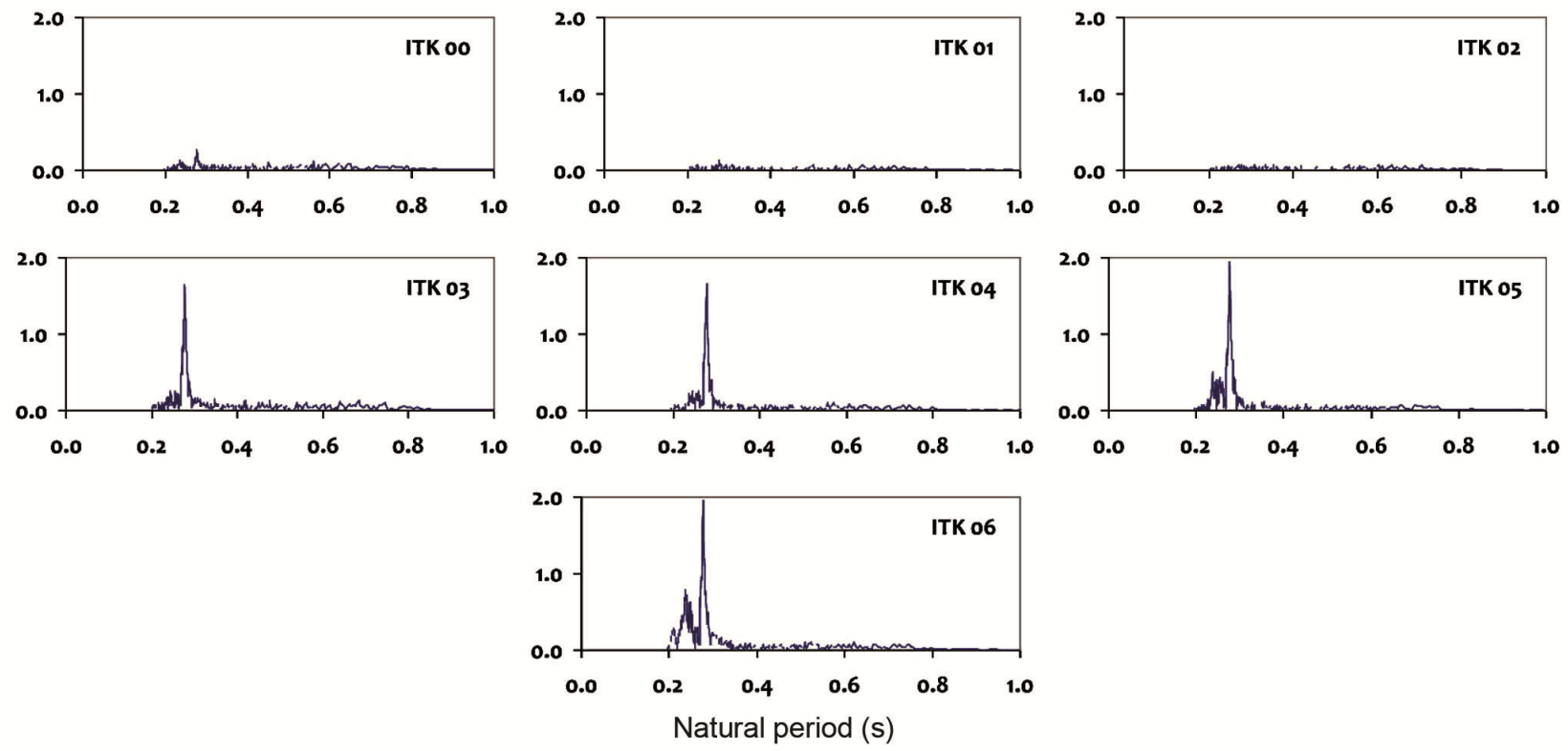

Figure 12. Fourier amplitude $\left(\mathrm{mm} / \mathrm{s}^{2}\right)$ spectra of acceleration of vibrations in the seven sensors recorded along E-W direction under blast 4 

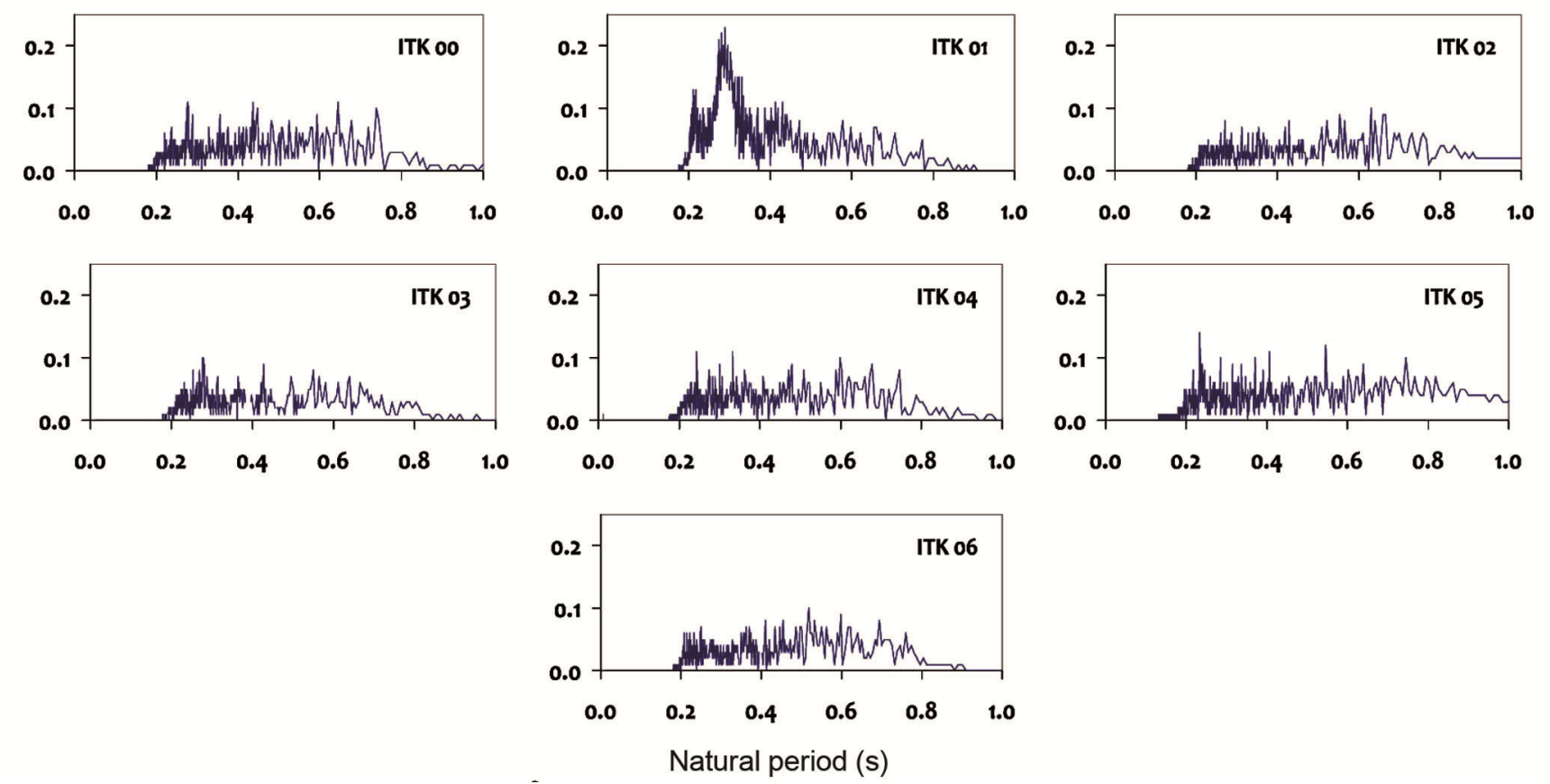

Figure 13. Fourier amplitude $\left(\mathrm{mm} / \mathrm{s}^{2}\right)$ spectra of acceleration of vibrations in the seven sensors recorded along the vertical direction under blast 4 .

Table 7. Peak Fourier acceleration spectral values of vibrations due to blasts

\begin{tabular}{llccccccc}
\hline \multirow{2}{*}{ Vibration } & \multicolumn{7}{c}{ Peak acceleration $\left(\mathrm{mm} / \mathrm{s}^{2}\right)$} \\
\cline { 3 - 9 } Blast 1 & Direction of measurement & 0 & 1 & 2 & 3 & 4 & 5 & 6 \\
& North-South & 0.15 & 0.08 & 0.10 & 1.04 & 0.62 & 0.54 & 0.87 \\
& East-West & 0.20 & 0.09 & 0.10 & 0.59 & 0.64 & 0.95 & 1.43 \\
& Vertical & 0.13 & 0.08 & 0.11 & 0.11 & 0.12 & 0.08 & 0.13 \\
Blast 2 & North-South & 0.12 & 0.07 & 0.08 & 0.47 & 0.26 & 0.15 & 0.23 \\
& East-West & 0.20 & 0.10 & 0.08 & 0.64 & 0.70 & 0.81 & 0.80 \\
& Vertical & 0.10 & 0.08 & 0.08 & 0.07 & 0.08 & 0.08 & 0.12 \\
Blast 3 & North-South & 0.13 & 0.11 & 0.08 & 0.79 & 0.45 & 0.34 & 0.46 \\
& East-West & 0.20 & 0.09 & 0.09 & 1.24 & 1.39 & 1.70 & 1.57 \\
& Vertical & 0.11 & 0.09 & 0.09 & 0.07 & 0.12 & 0.07 & 0.18 \\
Blast 4 & North-South & 0.18 & 0.10 & 0.11 & 0.58 & 0.95 & 0.65 & 1.09 \\
& East-West & 0.27 & 0.13 & 0.08 & 1.64 & 1.66 & 1.94 & 1.96 \\
& Vertical & 0.11 & 0.23 & 0.10 & 0.10 & 0.11 & 0.14 & 0.10 \\
\hline
\end{tabular}

blasting near the temple was assessed with four blasts, and a maximum charge of $\sim 70 \mathrm{~kg}$. The natural periods of the temple structure were 0.31 and $0.34 \mathrm{sec}$ along the $\mathrm{N}$ $\mathrm{S}$ and $\mathrm{E}-\mathrm{W}$ directions respectively, and for the $5 \mathrm{~m}$ thick clayey soil stratum underneath the temple, it was $0.11 \mathrm{~s}$. Since these periods of the structure and of the ground are well away from each other, there is no likelihood of increased response of the temple structure under any shaking of the ground. Also, even though the second translational natural mode of vibration of the temple structure has a natural period of $\sim 0.09 \mathrm{~s}$, which is close to the fundamental natural period of the soil stratum underneath, no significant amplification was noticed. The study shows that for all the levels of the blast, the spectral amplitudes decrease with increasing distance from the blast site, indicating attenuation in the amplitude of horizontal ground motion.

Maximum acceleration measured was $\sim 0.00006 \mathrm{~g}$ at the ground surface and $\sim 0.00019 \mathrm{~g}$ at the highest point of the temple structure. Also, peak particle velocity at the temple site for the largest blast (with $70.59 \mathrm{~kg}$ charge) varied in the range $0.10-0.39 \mathrm{~mm} / \mathrm{s}$, which was much less than that permissible $(5 \mathrm{~mm} / \mathrm{s})$ at the dominant excitation range of frequencies $(8-25 \mathrm{~Hz})^{11}$; and even at the highest point of recording the peak particle velocity increases to $0.39 \mathrm{~mm} / \mathrm{s}$. Therefore, it is concluded that the Ramappa Temple is not affected by the blasts undertaken at the Audit 4 Tunnel site (at a distance of $900 \mathrm{~m}$ with $70.59 \mathrm{~kg}$ charge) of the Devadula Lift Irrigation Project. 
Notwithstanding the above conclusion, the condition of the temple structure is poor. Unlike other temples (which in historic times were built on strong and elevated ground), the Ramappa Temple was founded on a $5 \mathrm{~m}$ thick clayey layer in the plains. The loss of three of the four structures around the temple over the last 800 years is testimony to the poor choice of the site. Significant efforts are required for the protection and restoration of the Ramappa Temple by applying appropriate structural interventions. This ensures the structure does not sustain detrimental deformation due the long-term deformation of the clayey soil stratum on which the temple has been constructed. This includes stiffening of the soil layer in the elevated pedestal of the temple to reduce flexibility of the soil stratum underneath the structure.

1. Rao, M. P., Engineering and technological achievements during the Kakatiya period. Report of the INTACH, Warangal Chapter, 1993.

2. Raghavachari, S., Shanker, N. B., Somayajulu, A. U. R. and Rao, M. P., Geotechnical appraisal and evaluation of Kakatiya monuments, REC, Warangal, 1991.

3. Chaudhuri, A. K., Stratigraphy and paleogeography of the Godavari Supergroup in the south-central Pranhita-Godavari valley, South India. J. Asian Earth Sci., 2003, 21, 595-611.

4. Kandpal, G. C., John, B. and Joshi, K. C., Geotechnical studies in relation to seismic microzonation of Union Territory of Chandigarh. J. Indian Geophys. Union, 2009, 13(2), 75-83.
5. IS1893:2002, Indian standard criteria for earthquake resistant design of structures. Bureau of Indian Standards, New Delhi, 2002.

6. Chung, W. Y., Source parameters of two rift associated intra plate earthquakes in peninsular India: the Bhadrachalam earthquake of 13 April 1969 and the Broach earthquake of 23 March 1970. Technophysics, 1993, 225(3), 219-230.

7. Nakamura, Y., A method for dynamic characteristics estimation of subsurface using microtremor on the ground surface. In Quarterly Report of the Railway Technology Research Institute, Japan, 1989, 30, 25-33.

8. Bonilla, L. F., Steidl, J. H., Lindley, G. T., Tumarkin, A. G. and Archuleta, R. J., Site amplification in the San Fernando Valley, California: variability of site-effect estimation using the S-wave, coda, and H/V methods Bull. Seismol. Soc. Am., 1997, 87, 710730 .

9. Coutel, F. and Mora, P., Simulation based comparison of four siteresponse estimation techniques. Bull. Seismol. Soc. Am., 1998, 97029, 1-22.

10. Boore, D. M., Simulation of ground motion using the stochastic method. Pure Appl. Geophys., 2003, 160, 635-676.

11. DGMS, Circular No. 7, Directorate General of Materials and Stores (Tech) (S\&T), Government of India, 1997.

ACKNOWLEDGEMENTS. We thank the Director, CSIR-National Geophysical Research Institute, Hyderabad for providing the necessary support and infrastructure for the study. We also thank the Irrigation and Command Area Development Department of the then Government of Andhra Pradesh for funds.

Received 16 December 2019; revised accepted 17 July 2020

doi: $10.18520 / \mathrm{cs} / \mathrm{v} 119 / \mathrm{i} 7 / 1131-1141$ 